\title{
How do collaboration and investments in knowledge management affect process innovation in services?
}

Article

Accepted Version

Ashok, M., Narula, R. and Martínez-Noya, A. (2016) How do collaboration and investments in knowledge management affect process innovation in services? Journal of Knowledge Management, 20 (5). pp. 1004-1024. ISSN 1367-3270 doi: https://doi.org/10.1108/JKM-11-2015-0429 Available at https://centaur.reading.ac.uk/66214/

It is advisable to refer to the publisher's version if you intend to cite from the work. See Guidance on citing.

To link to this article DOI: http://dx.doi.org/10.1108/JKM-11-2015-0429

Publisher: Emerald

All outputs in CentAUR are protected by Intellectual Property Rights law, including copyright law. Copyright and IPR is retained by the creators or other copyright holders. Terms and conditions for use of this material are defined in the End User Agreement.

www.reading.ac.uk/centaur 
Central Archive at the University of Reading

Reading's research outputs online 


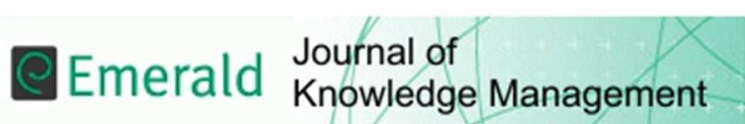

\section{HOW DO COLLABORATION AND INVESTMENTS IN KNOWLEDGE MANAGEMENT AFFECT PROCESS INNOVATION IN SERVICES?}

\begin{tabular}{|r|l|}
\hline Journal: & Journal of Knowledge Management \\
\hline Manuscript ID & JKM-11-2015-0429.R2 \\
\hline Manuscript Type: & Research Paper \\
\hline Keywords: & $\begin{array}{l}\text { Knowledge management, service industry, PLS-SEM, Process Innovation, } \\
\text { radical innovation, User collaboration }\end{array}$ \\
\hline \multicolumn{2}{|l}{} \\
\hline
\end{tabular}

SCHOLARONE $^{\text {M }}$
Manuscripts 
HOW DO COLLABORATION AND INVESTMENTS IN KNOWLEDGE MANAGEMENT

\title{
AFFECT PROCESS INNOVATION IN SERVICES?
}

\begin{abstract}
Purpose: Despite the keen interest in radical and incremental innovation, few studies have tested the varying impact of firm-level factors in service sectors. This paper analyses how collaboration with existing and prospective users, and investments in knowledge management (KM) practices can be adapted to maximise the outputs of radical and incremental process innovation in a KnowledgeIntensive Business Service (KIBS) industry.

Methodology: Original survey data from 166 Information Technology Service (ITS) firms and interviews with 13 executives provide the empirical evidence. PLS-SEM is used to analyse the data.
\end{abstract}

Findings: Collaboration with different types of users, and investments in KM practices affect radical versus incremental process innovation differently. Collaboration with existing users influences incremental process innovation directly, but not radical innovation; and prospective user collaboration matters for radical, but not incremental innovation. Furthermore, for radical innovation, investments in KM practices mediate the impact of prospective user collaboration on innovation.

Implications: While collaboration with existing users for incremental process innovations does not appear to generate significant managerial challenges, to pursue radical innovations firms must engage in intensive collaboration with prospective users. Higher involvement with prospective users requires higher investment in KM practices to promote efficient intra- and inter-firm knowledge flows. 
Originality: This study is based on a large-scale survey, together with management interviews.

Radical and incremental innovations in the service industry require engagements with different kinds of users, and the use of knowledge management tools. 


\section{INTRODUCTION}

Radical and incremental innovations are key constituents of a firm's strategy to sustain competitive advantage. Together they strengthen the future innovation paths available to a firm. Radical innovations are associated with the long-term competitiveness of a firm and their implementation entails a greater level of change, which results in a friction between the old and new way of working (Ettlie et al., 1984; Norman and Verganti, 2014). In contrast, incremental innovations are perceived as less disruptive. Firms implementing incremental change work on familiar knowledge, encounter lower uncertainty, and try to protect their current market share; thereby engage in a search for knowledge that is in close proximity to their current knowledge-base (Zahra and George, 2002; Kim et al., 2014).

Firms are challenged by the need to adjust their strategies for the implementation of both radical and incremental innovation, and often find it difficult to strike a balance between them (Garcia and Calantone, 2002; Norman and Verganti, 2014). Nevertheless, theoretical and managerial guidelines on the topic are limited. Past studies report that the influence of factors is often similar (or does not vary) across radical and incremental innovation (Van Riel et al., 2004; Damanpour, 2010). In addition, there is scarce empirical investigation of the organisational environment or formal knowledge management (KM) practices that support the introduction of new-to-firm and new-tomarket innovations (Arundel et al., 2006). Indeed, despite the key role of external knowledge for radical change, and the key role of users in the service sector, there is a limited understanding of the influence of collaboration on incremental and radical innovation.

This paper analyses how user collaboration and investments in knowledge management (KM) practices influence the outputs of process innovation in a particular Knowledge-Intensive Business Service (KIBS) industry: the Information Technology Services (ITS). KIBS firms play a vital role in the knowledge-based economy, and they are key enablers, sources, and users of innovation. User collaboration is especially integral to the provision of IT services, where both existing and new users 
co-create knowledge with these providers (Salter and Tether, 2014). However, the feasibility of such co-creation and its impact on a firm's performance lacks clarity (Santos-Vijande et al., 2013).

Similarly, there is lack of consensus on how user collaboration influences the performance of radical, in comparison to incremental, innovation (Gustafsson et al., 2012). Thus, our first research question is: (i) Does collaboration with existing and prospective users show a differing impact on radical versus incremental process innovation?

We also analyse the effect of a firm's investments in KM practices on innovation in response to the research gaps identified by Serenko and Dumay (2015). This is because knowledge is a key firm-level asset, and the benefits from knowledge exchanges (through collaboration) are not automatic. They are dependent on a firm's absorptive capacity, which is the firms' capability to integrate, internalise and exploit external knowledge for financial gains (Cohen and Levinthal, 1990). We argue, given that KM practices are fundamental to the way services are co-created by ITS firms and their users, investments in KM practices become key to increase this absorptive capacity, as they enable the firm to build capabilities to translate external knowledge into firm-specific competences (Salter and Tether, 2014). Efficient KM practices allow the ITS providers to translate learning from a customised solution to generic offering (Doroshenko et al., 2013). As a result, the second research question considered is, (ii) Do investments in KM practices mediate the impact of collaboration on radical and incremental process innovation?

Given that the implementation of radical innovation entails a higher degree of change and a higher friction between the old and new ways of working (Du Plessis, 2007), the third research question is, (iii) Do investments in KM practices show differing impact on radical versus incremental process innovation?

Our paper begins with a discussion of the theoretical background and defines the hypotheses for testing. We then describe our survey data from the 166 ITS firms that constitute the empirical evidence for our study, and analyse this data using the PLS-SEM advanced techniques. The results 
obtained are also validated with qualitative data stemming from the feedback received from 13 executives. Finally we conclude with a discussion of the theoretical and managerial implications of our study.

\section{THEORETICAL BACKGROUND AND HYPOTHESES}

The concept of radical innovation dates back to Schumpeter's (1961) seminal work. Later studies drew attention to the fact that successful radical innovation is rather rare; in fact, most firms benefit from incremental innovation which extends the benefit of the dominant design, technology, product, or process (Norman and Verganti, 2014) ). Although, radical and incremental innovations are undertaken for distinct objectives and entail varying degrees of change, a balanced approach towards the implementation of both types of innovation leads to sustained performance in the long-run; especially in the service sector (Damanpour et al., 2009) and in the context of software process innovations (Fichman and Kemerer, 1997).

In this study, process innovation is defined as the implementation of a new or significantly improved production or delivery method that is of value to the user; process innovation includes significant changes in techniques, equipment and/or software (OECD, 2005). Radical and incremental innovation are viewed as the higher and lower extremes of degrees of innovativeness: which represents the degree of departure of innovation from the current paradigm or current state at the innovating firm (Reichstein and Salter, 2006; Norman and Verganti, 2014). We define radical process innovation as the delivery of 'new to the market' methods, and incremental process innovation as the delivery of either 'significant improved' or 'new to the firm' methods (Tether, 2002; Van Riel et al., 2004).

Although, the need for incremental and radical innovation for sustained competitive advantage is understood (Bauer and Leker, 2013), managers face challenges in allocating limited resources to the degrees of innovativeness. The existing literature on radical (exploratory) and 
incremental (exploitative) innovation remains unclear on the factors influencing these innovations (Jansen et al., 2006). The objective of this study is, therefore, to improve the predictability of the degree of process innovativeness in KIBS firms, more specifically in the ITS providers, through the control of user collaboration and investments in KM practices. Following Damanpour, 1991, we expect that the impact of the factors studied on radical and incremental process innovation outcomes will vary in the strength of relationship, but not in the direction. The research model and the hypotheses tested are captured in Figure 1.

-----Figure 1 about here-----

\subsection{Collaboration}

Although extensively discussed, the differential impact of collaboration on radical and incremental innovation lacks "systematic evidence" (Jansen et al., 2006, p. 1661), a gap addressed in this paper. We define collaboration as the joint creation of value by a firm and its partners, which involves exchange, sharing and co-development (Gulati, 1995; Prahalad and Ramaswamy, 2004) ${ }^{1}$. Although KIBS firms can benefit from collaborating with a wide variety of partners, collaboration with users in the ITS context has been found to be especially important because these providers depend on user information more heavily that other service providers or manufacturing firms (Hertog, 2000). In fact, previous studies show that the user-ITS firm collaboration triggers knowledge transfer and innovation across both partners (Doroshenko et al., 2013). Therefore, within our research model we focus on collaboration with end-users (existing and prospective) because they are intrinsic to the operations of ITS firms.

\footnotetext{
${ }^{1}$ Thus, outsourcing arrangements where there is no active engagement with the partner is not regarded as collaboration.
} 


\subsubsection{Existing and prospective user collaboration}

Users are the consumers and co-producers of value and they expect benefit from using a product or service. Existing users are consumers who have a working relationship with the firm, and prospective users are new consumers the firm wishes to acquire in an existing or a target market. The co-creation of value with users is intrinsic to a KIBS firm's operations (Salter and Tether, 2014). KIBS firms employ personnel who combine professional knowledge and customer inputs to develop innovative services in response to customer needs. Despite the importance of the topic, several research gaps exist. There is lack of consensus on how and whether user collaboration benefits radical and incremental innovation performance differently (Gustafsson et al., 2012).

Firms that wish to minimise risks tend to respond to demands from current users, which normally results in incremental improvements (von Hippel, 2005; Robertson et al., 2012). Firms develop expertise in problem-solving through repeated practice; however over-specialisation in current capabilities deters them from straying too far from the current knowledge-base (Hienerth et al., 2014). Existing users are impacted by the "functional fixedness" effect: they tend to perceive the future application of innovation within their existing frame of knowledge, which generates incremental change and blocks radical application (Hienerth et al., 2014, p. 191). Therefore, engagement with existing users is more likely to lead to incremental innovation.

In contrast, firms that are more risk oriented, tend to explore novel innovation opportunities, and are more likely to collaborate with new or prospective users (Jansen et al., 2006). Indeed, users that are open to experimentation are able to visualise a novel solution and formulate complex strategies for the adoption of radical innovation (Hienerth et al., 2014). For example, in the study of the effect of customer interaction on new product performance, Menguc et al. (2014) find that interactions with existing customers had a significant but negative effect on the performance of radical innovation. These authors conclude that firms adopting radical innovation will benefit by interacting with new or lead users. 
Based on these ideas, we present the following argument. Collaboration with existing users is constrained by their current experiences, whilst prospective users (perhaps due to their experiences with other firms or industries) can help a firm to fundamentally change its processes. We argue that engagement with existing users is expected to lead to incremental process innovation. In contrast, because radical change takes a firm away from its current competences, we expect collaboration with prospective users to show a greater impact on radical (as compared to incremental) process innovation.

Hypothesis 1 (H1): Existing user collaboration will show a greater impact on incremental (as compared to radical) process innovation.

Hypothesis 2 (H2): Prospective user collaboration will show a greater impact on radical (as compared to incremental) process innovation.

\subsection{Investments in KM practices}

A key usage of the information assimilated from external partners is to implement innovation, which however creates a friction between the old and new knowledge. Consequently, firms need to dedicate internal resources to create KM practices that enable the development of absorptive capacity and the undertaking of process innovation. In this paper, $K M$ is defined as a capability to leverage (internal and external) knowledge in order to enable superior performance, encourage innovation, and enhance customer value (Gold et al., 2001; Du Plessis, 2007). KM practices are critical in today's dynamic and competitive business context, because they enable innovation by maximising the benefits extracted from tacit knowledge and facilitate collaboration (Du Plessis, 2007; Jones and Mahon, 2012). Thus, KM practices are fundamental to the way services are co-created by KIBS firms and their customers. The importance of KM practices is emphasised for our research context, because ITS firms' KM practices are essential to capture and translate external learning into firm-specific capabilities (Salter and Tether, 2014). Indeed, ITS firm's KM practices is a fundamental part of their 
activity, as collaboration with customers lies at the heart of this sector (Doroshenko et al., 2013).

However, as argued by Heisig's (2015) review of the KM literature, there is still a challenge in demonstrating a link between investments in KM practices and organisational outcomes.

Although the importance of designing formal KM practices for innovation is widely researched, investments in KM practices to support absorptive capacity in the context of radical innovation has not been widely investigated (Lane et al., 2006). Radical innovation not only requires the effective recognition of valuable external knowledge, but it also calls for the creation of absorptive capacity to internalise new knowledge. Furthermore, as discussed above, radical change represents a clear departure from a firm's current state of affairs. Therefore, we expect that the implementation of radical (as compared to incremental) process change will require higher investments in KM practices to integrate new and diverse knowledge through the creation (or adoption) of new capabilities, technologies, and training programmes.

Resources allocated to KM practices are of a greater importance for radical process change because these practices help a firm to search the environment for new trends (Camp, 1989; Kang and Kang, 2014). For instance, benchmarking is an important KM tool that enables firms to reduce the cost of innovation and control risks (Du Plessis, 2007). Previous studies show that the value extracted from radical innovation is limited by a firm's knowledge and capabilities (Sorescu et al., 2003). Thus, we argue that investment on KM practices will be more beneficial for firms that implement radical, as against incremental process innovations, as these investments will generate the internal capability to translate new and diverse knowledge into firm-specific benefits. Hypothesis 3 (H3): Investments in KM practices will show a greater impact on radical (as compared to incremental) process innovation. 


\subsection{Investments in KM practices mediate the impact of user collaboration on process} innovation

There is a tension between the absorption of knowledge associated with incremental innovation and the adoption of novel knowledge associated with radical innovation (Ritala and HurmelinnaLaukkanen, 2013). Investments in KM practices helps firms to mitigate this tension through the development of internal innovation capabilities that are needed to translate external knowledge efficiently into the organisational context. Du Plessis (2007) discusses that collaboration with partners enhances the gathering of tacit knowledge, and positively impacts the KM practices, which in turn help firms to control the costs and risks of innovation. We therefore argue that the impact of user collaboration on the degrees of innovativeness will be mediated by the extent to which the firm invests in KM practices, as these investments will shape the firm's absorptive capacity.

Theoretical models of absorptive capacity, argue that a firm's internal innovation capability will mediate the benefit of external knowledge sources on innovation (Zahra and George, 2002; Lane et al., 2006). Prior research shows that the translation of user knowledge into a firm-specific advantage is especially complex; information shared by users is not valuable unless a firm invests resources to interpret this knowledge within the organisational context (Nicolajsen and Scupola, 2011). KIBS firms have to promote a fusion of their knowledge set and that of the client's. However, this asymmetry of knowledge between the customer and the KIBS firm can prove challenging (Santos-Vijande et al., 2013). It will be easier to assimilate the knowledge of existing users, because experience mitigates absorption, and pre-existing routines will assist firms in internalising customer knowledge sets, relative to prospective customers. In contrast, greater investments in KM practices are required to assimilate the knowledge residing in prospective users and make it useful for achieving to radical innovations. Thus, we hypothesise that: 
Hypothesis 4A (H4A): The impact of existing user collaboration on process innovation will be mediated through investments in KM practices, being greater for incremental, as compared to radical, process innovation.

Hypothesis $4 B$ (H4B): The impact of prospective user collaboration on process innovation will be mediated through investments in KM practices, being greater for radical, as compared to incremental, process innovation.

\section{RESEARCH DESIGN}

\subsection{The sample}

The data used for hypotheses testing came from survey responses from 166 ITS firms and discussions with 13 executives, who validated the findings. ITS firms play a central role in the economy: they work very closely with their users, often in multi-disciplinary teams. They facilitate their client firms to translate new information, and extract tacit knowledge from these partners. The study of the factors that impact radical and incremental innovation in ITS is of particular importance because they are also known to deliver projects with varying degrees of innovativeness (Salter and Tether, 2014).

We adopt Gartner's taxonomy to identify firms operating in the ITS industry; these firms are involved in consulting, implementation, IT outsourcing, business process outsourcing, and software support and hardware support (Blackmore and Hale, 2012). We designed an online questionnaire to collect the data. We followed Campbell's (1955) guidelines to check that the informants are competent to respond to the questionnaire. We took various steps to boost the response rate and enhance the precision of the responses. ${ }^{2}$ Instructions were provided for the informants to reflect (on behalf of their firm) on their activities for the last year and to complete the survey at the Business

\footnotetext{
${ }^{2}$ Informants were contacted via email to explain the research context, to discuss the potential business implications of the survey and to assure confidentiality; we also promised to share the research summary with our contributors. Senior managers were chosen as respondents, as they are more likely to understand their firm's perspective on the research topic.
} 
Unit level if they performed various roles. The questionnaire was sent out in three waves in May, July, and October 2012. The sample for this study was obtained from two sources: from experienced postgraduate network members and a professional networking site. ${ }^{3}$ The choice of these sources is appropriate for our research's focal industry because ITS providers are lead users of social networks and communication channels. Additionally, these firms use these channels to attract a skilled workforce and to connect with their online-active users; these providers are known to exploit valuable knowledge exchanged on these networks (Ridder and Cohen, 2013).

The questionnaires were sent to 612 respondents. After cleansing the data, a usable sample of 166 responses was obtained. ${ }^{4}$ This gave us a 27 percent response rate, which is comparable to response rates in previous organisational studies (Baruch and Holtom, 2008); especially on the topic of innovation (Sauermann and Roach, 2013). We ascertained that the sample size met guidelines discussed in Bartlett et al. (2001), Tabachnick and Fidell (2007), and Hair et al. (2013). In light of the sampling method, we tested for non-response bias using accepted procedures. We compared responses based on the wave that the survey were sent out, the time taken to complete the survey, and the early and late responses across the waves (Armstrong and Overton, 1977). No evidence of difference was found in these tests.

\subsection{The variables and measures}

New scales for all the constructs were developed in line with Churchill (1979) guidelines, as appropriate existing scales were not found. Although the European Union's Community Innovation Survey (EU CIS) and its customised versions have substantially influenced our body of knowledge on innovation, these surveys do not incorporate detailed indicators on the depth and breadth of

\footnotetext{
${ }^{3}$ Sources include the Henley Business School's postgraduate programmes for experienced professionals and LinkedIn. ${ }^{4}$ Responses with less than 25 percent missing data were used; responses of 'Not Applicable' and 'Don't Know' were treated as system-defined missing data. Outliers were deleted and special attention was given to missing data analysis. This is because missing data creates an issue for further analysis using structural equation modelling (Allison, 2003). We concluded that the data was missing completely at random because Little's MCAR test showed p $>0.05$. The EM algorithm was used to replace missing data, which is an accepted practice for latent variable models and factor analysis (Schafer and Graham, 2002).
} 
process innovation, knowledge management practices adopted by KIBS firms to enable process change, and extent of user collaboration. There are also limited guidelines on how to measure KM practice (Darroch, 2003), and previous studies' use of R\&D expenditure as a proxy for a firm's investments in KM practices (to develop absorptive capacity) has been criticised (Lane et al., 2006). We identified a mix of three inward- and two outward-looking management practices based on the recommendations by Foss et al. (2011) with the attempt to capture investments in KM practices contributing to develop absorptive capacity in the service sector. The inward-looking indicators of investments in KM practices were investigated because they help the firm to learn and break away from the old ways of working (Zairi and Sinclair, 1995). The outward-looking indicators of investment of KM practices in benchmarking were used to assess a KIBS firm's strategy towards process performance comparison (Anderson and McAdam, 2004). New measures were validated through discussions with 28 executives, whose feedback was used to improve the clarity of the instrument. The questionnaire was further pilot-tested with 41 executives.

We defined the research model as a reflective model, where the indicators were created to reflect the underlying construct (Chin, 1998a). The reflective indicators were defined on a one-toseven scale because this allowed us to capture a greater variation in the responses in comparison to a five-point scale (Lietz, 2010). We labelled only the extremities: scale one was labelled as 'Strongly Agree' and seven as 'Strongly Disagree'. In order to perform group-analysis, we first established that the indicators perform adequately across the sub-groups (Chin and Dibbern, 2010), and took steps to address redundancy issues among the indicators (Cronbach, 1951). The constructs, their measures and loadings are captured in Table 1.

-----Table 1 about here----- 


\subsection{The method of analysis}

\subsubsection{Use of mixed methods}

Mixed methods were used to investigate the research questions. The online survey was followed by qualitative interviews with ITS executives to validate the survey findings and to delve deeper into ITS firms' strategies relating to radical versus incremental process change. Mixed methods reduce the uncertainty of interpretation of results and can be a superior approach in social science to highlight convergence, inconsistency, and contradiction across the data sources (Johnson et al., 2007).

\subsubsection{Survey data analysis}

We adopted partial least squares-structural equation modelling (PLS-SEM) techniques for our exploratory study and use SmartPLS (Ringle et al., 2005). This is because our research objectives did not meet the assumptions laid down by covariance based-structural equation modelling. The use of PLS is suitable because we developed an exploratory theory to ascertain the differing impact of firmlevel factors on radical versus incremental process innovation. Our aim was to maximise the predictability of the dependent construct: process innovation (Hair et al., 2013). Further, PLS path modeling generates reliable results with a smaller sample size and is preferred for a complex model (Henseler et al., 2009).

We followed the guidelines for the selection of PLS-SEM, and met the sample size requirements to conduct a group-analysis using PLS path modelling (Chin, 1998b; Hair et al., 2013). ${ }^{5}$

Group-analysis was undertaken by segmenting the data based on the degree of innovativeness. The respondents were instructed to report the proportion of radical and incremental process innovations implemented in the last year, where the online survey tool mandated that these proportions add up to 100 percent. The median value of radical process innovation (as per guidelines

\footnotetext{
${ }^{5}$ The sample size required for a PLS group-analysis is ten times the maximum number of (i) formative indicators for a construct, or (ii) structural paths to an endogenous construct. Since we use reflective indicators in our study, the sample size requirement is based on the maximum number of paths to an endogenous construct, which is three paths, thus the required sample size is 30 cases per sub-group; this criterion is met.
} 
in Sosik et al. (2009)) was used to split the data to identify firms implementing relatively more radical, in comparison to more incremental, process innovation. This gave 58 sample cases for the radical process innovation sub-group and 75 cases for the incremental sub-group. Descriptive analysis (captured in Table 2) was followed by the assessment of the inner and outer models across the sub-groups using accepted procedures. Furthermore, to assess common method bias arising due to the use of a single source for dependent and independent variables, an ex-post Harman's one factor test was undertaken. The un-rotated factor analysis results reveal that there was no common factor loading on all the measures, thus common method bias was regarded as insignificant (Podsakoff and Organ, 1986). Finally, a post-hoc statistical power analysis was undertaken, which demonstrated strong support for our research model, with an observed statistical power greater than 0.99 for both sub-groups. ${ }^{6}$

-----Table 2 about here-----

\subsubsection{Interview data analysis}

The findings from the survey responses were further corroborated by undertaking in-depth discussions with 13 executives from the focal industry. These executives did not participate in the online survey. They were selected for the discussions because of their extensive knowledge of the research topic: implementing process innovation (see Table 3). They had an average of 20 years of professional experience each. The interviews were recorded and transcribed; the transcripts were sent back to the participants for validation. A thematic analysis technique was used to interpret and report the interview findings.

-----Table 3 about here-----

\footnotetext{
${ }^{6}$ Used Post-hoc Statistical Power Calculator for Multiple Regression [Software accessed on 22nd Feb 2016], entered probability level as 0.05 , number of predictors as three, and the respective observed $\mathrm{R}^{2}$ and sample size values. http://www.danielsoper.com/statcalc3/calc.aspx?id=9
} 


\section{RESULTS}

\subsection{Quantitative data results}

We use the guidelines to test reflective inner and outer models for PLS-SEM (Chin, 1998a; 1998b; Henseler et al., 2009).

\subsubsection{The outer model (measurement model)}

We check that the measures perform adequately across the sub-groups (Chin and Dibbern, 2010) and the reliability and validity of the constructs is assessed across the sub-groups (see Table 4). The composite reliability measure is used, as opposed to the Cronbach's alpha value (Chin (1998a), Henseler et al. (2009)). All constructs report composite reliability values greater than 0.88 , so exceeding the 0.7 criterion across the sub-groups. The construct's convergent validity is ascertained because the average variance extracted (AVE) is greater than 0.5 for all the sub-groups' constructs. Finally, discriminant validity is tested in three ways: by the qualitative assessment of face validity, by checking construct cross-loadings (Chin, 1998b) - Table 5, and by checking that the square root of all the sub-groups' construct's AVE is greater than the correlation with the other constructs (Henseler et al., 2009) - Table 6. The bootstrap analyses use 5000 samples and the number of cases for each sub-group.

-----Table 4 about here----

-----Table 5 about here-----

-----Table 6 about here-----

\subsubsection{The inner model (structural model)}

We assess the inner model in Table 7 and its paths in Figure 2. Unlike the covariance based-SEM, PLS does not have a global goodness-of-fit index; hence various tests, discussed in Chin (1998b), are undertaken to assess the robustness of the results and to investigate the explanatory power of process innovation. We evaluate the issue of multi-collinearity of the predictor constructs, and find no 
concerns as all the VIF values are less than 5 across the sub-groups (Hair et al., 2013). We also undertake blindfolding and find that the model has predictive relevance, since the $\mathrm{Q}^{2}$ values are greater than zero for both the endogenous variables across the sub-groups (Hair et al., 2013). ${ }^{7}$

The hypotheses are tested in a four-step process: firstly, by inspecting the standardised path coefficients (and their t-values) obtained through bootstrapping (Error! Reference source not found.); secondly, by comparing the effect sizes (using Cohen's (1992) guidelines) of the predictor constructs on the endogenous constructs (Table 7); thirdly, by comparing the construct mean values across the sub-groups (Table 8); and fourthly, by assessing the significance of the path coefficient differences (Table 9). Special attention is paid to checking that the standardised path coefficients are at least 0.20 so as to be considered meaningful (Chin, 1998a).

----- Figure 2 about here-----

----- Table 7 about here-----

----- Table 8 about here-----

----- Table 9 about here-----

\section{Quantitative data results}

$\mathrm{H} 1$ is partially supported, because the direct impact of existing user collaboration on process innovation is significant only for incremental process innovation; it is weak and insignificant for radical process innovation. Further, the size effect of existing user collaboration on process innovation is higher for the incremental process innovation sub-group. Although the path coefficient difference and the mean difference (of the existing user collaboration construct) are as hypothesised, these differences are not significant.

$\mathrm{H} 2$ is supported; the direct impact of prospective user collaboration is significant only for radical process innovation. Further, the mean difference of prospective user collaboration is greater

\footnotetext{
${ }^{7}$ The distance is set at six. The rule for setting the distance for blindfolding is that the sample size should not be divisible by the distance, and the distance should be set between five and ten (inclusive) (Hair et al., 2013).
} 
for radical process innovation and the difference is significant at 0.00 (two-tailed). Similarly, the difference in the path coefficients for $\mathrm{H} 2$ is significant at 0.03 (one-tailed).

$\mathrm{H} 3$ is supported because radical process innovation shows a greater impact of investments in KM practices (with the mean difference significant at 0.01 level, two-tailed) and a greater effect of investments in KM practices (the difference in the path coefficients is significant at 0.10 , one-tailed). Furthermore, the effect size of investments in KM practices on process innovation is larger for the radical sub-group.

In $\mathrm{H} 4$, investments in $\mathrm{KM}$ practices are expected to mediate the impact of collaboration on process innovation. Baron and Kenny's (1986) three step guidelines are used to test the mediation effect of investments in KM practices on the impact of user collaboration on process innovation. Additionally, Sobel's (1982) test for indirect effect of the independent variables on the dependent variable is undertaken and the results corroborate the inferences drawn on the mediation effect.

Firstly, H4A is not supported. As mentioned above, the impact of existing user collaboration is significant only for incremental process innovation; and this impact is direct thus not mediated through investments in KM practices. Additionally, existing user collaboration has a small effect on investments in KM practices across the sub-groups. This suggests that in the ITS context, existing users are endogenous to a firm's incremental process change. The extraction of value from existing user collaboration seems to happen in conjunction with the normal operation of a KIBS firm.

H4B is supported, as the impact of prospective user collaboration on radical process innovation is fully mediated by investments in KM practices. Firms implementing radical process innovation show a greater impact of prospective user collaboration on investments in KM practices (path coefficient difference is significant at 0.01 level, one-tailed) and in turn a greater impact of investments in $\mathrm{KM}$ practices on process innovation. Further support comes from the investigation of the effect size of prospective user collaboration on investments in KM practices across the sub- 
groups; this effect is large for radical process innovation and small for incremental process innovation.

Using our research model, firms implementing radical process innovation in our sample reported a $\mathrm{R}^{2}$ of 0.56 , in comparison to the $\mathrm{R}^{2}$ of 0.35 reported by incremental process innovation firms. Although the evaluation of $\mathrm{R}^{2}$ depends on the context and the conceptualisation of the constructs, scholars propose that an $\mathrm{R}^{2}$ value of around 0.30 is satisfactory (Chin, 1998b; Henseler et al., 2009), and our results meet this criterion. However, the difference in $\mathrm{R}^{2}$ values (between radical and incremental process innovation sub-groups) is not statistically significant, because the 95 percent confidence interval for this difference is $[0.46,-0.03]$ includes the value zero (Olkin and Finn, 1995). Though, we conclude that KIBS firms can improve the certainty of radical process innovation with the use of appropriate user collaboration and KM practice policies; they can demonstrate a predictive power that is similar to (if not better than) incremental process innovation using our model.

\subsection{Qualitative data results}

Our interviews reiterated the importance of user collaboration for process innovation in ITS firms. Extracts of our discussion with an executive emphasises this point:

"[ITS firms] need to employ [a] bunch of people who will understand the unmet needs today and a bunch of people who will imagine the future needs and together they can help decide what is important for the future. Before you undertake process innovation, go out to your existing and prospective end-users and [then] come back and decide what is required."

The interviews confirmed H1 that existing user collaboration only seems to influence incremental process innovation. In the words of some of our ITS executives:

"Existing users fully understand/comprehend the current process. Their contribution would primarily be in the form of suggestions towards enhancements, which translate to change requests. [These requests] result in upgrades that are incremental in nature - a release based model with minor revisions to the process version every few months." 
"I agree, if you or I are going through process innovation and engage with existing endusers, who are living in a certain environment and [are] focused on the current rather than the future needs; they are more likely to help with incremental change."

"For incremental process innovation, we tend to work on the same things or similar themes [...] There is no real variation in our approach to process issues. So we engage with known and current end-users as against trying a new relationship."

The quantitative data also confirms H2, that collaboration with prospective users' matters more when firms are interested in radical innovation. This view resonates with the sentiments expressed in the following responses taken from a selection of the ITS executives:

"The best example I can give you, before we went and created a new business model we went to 250 Small and Medium Entrepreneurs, who were all prospective end-users. The power of prediction [of radical process innovation] went incrementally up, because we collaborated with them very effectively to define what is required."

"If there is larger participation by prospective end-users, then the organisation shows a strong and aggressive drive for process change. Also, by involving the prospective end-users the firm has taken care of the future expectations."

"New users bring in a fresh perspective which is totally new and unbiased with regard to the existing features and functionality. This fresh perspective and view of process capabilities [...will] results in a complete overhaul or reengineering of the process; a new process architecture bearing little or no resemblance to the as-is but yet achieving higher capabilities and maturity levels."

\begin{abstract}
Although the degree of innovativeness differentiates the impact of existing and prospective user collaboration on process innovation, the quantitative analysis found that existing user collaboration influences incremental process innovation directly, and was not mediated by investments in KM practices. ITS firms seemed to be using ongoing engagement with existing users as an effective mechanism to influence incremental process change. Service firms tend to use inexpensive and easier
\end{abstract}


market research tools (like complaint management, observations and interviews/questionnaires) to search for user ideas; however these tools are intrinsically related to the existing services, and hence ideas generated using these tools lead to incremental innovation (Skiba and Herstatt, 2008). Current users are not only fundamental to the firms' operations, but are endogenous to incremental process change, a view supported by our executive respondents, two of whom said:

"It is always easier to collaborate with existing end-users, [while] prospective end-user collaboration requires organisational will."

"Incremental change takes a short term view, and it happens in the current environment, so there is less [organisational] focus [...] Remember, in the short term, the organisation is unable to alter its competencies (significantly) to respond to market changes, [...or] imitate novel technological advances and underlying practices [...Therefore] the current customer engagement processes are key for incremental process innovation, as they help the organisation to learn and internalise existing end-user knowledge."

Why does user collaboration affect incremental innovation directly, but radical innovation only indirectly, through investments in KM practices? In the services context, incremental process innovation happens through the ongoing process of value co-creation with existing users, thus requiring no additional resource commitment. However, radical change requires higher investments in $\mathrm{KM}$ practices to enhance internal capabilities to translate new (and new combinations of) knowledge into firm-specific outcomes. The executives' summarised the reasons for the divergent strategies as follows:

"Let me give you a scenario, [an]organisation already had a [quotation] system and was working continuously with its stakeholders, including existing end-users, to improve parts of the process. The objective was to continually improve the productive and reduce the timeline; [thus] incremental improvements just happened all the time. [However...] the organisation was challenged to reduce the quotation time drastically for [new] high value customers.[...] Based on the need for a radical process change, [...] the organisation committed substantial resources [for KM practices], and included prospective end-users." 
"In order to do radical innovation, humongous commitment towards knowledge management is required, [because] the risks are very high and the time it takes to implement radical innovation is also very long. In contrast, the problem statement for incremental change will primarily come from an ongoing relationship with our existing customers

"For me the purpose of collaboration for incremental change is a learning journey; [...where] the method by which collaboration happens can happen without the existing customer knowing it is going on.[... By contrast,] radical innovation challenges the dominant paradigm. So radical innovation is when the trend line bends. [...] The important thing is that it [radical innovation] impacts a lot of people and you have to bring [them] with you. The business commitment [to KM practices] is not only necessary to convince the people inside the organisation, but also essential to get [external] key shareholders on board."

Overall, we found that firms implementing radical process innovation showed a greater commitment in, and enjoyed a greater benefit from, investments in KM practices. This result is unanimously supported by our executive respondents:

"I would imagine the in-house competencies [built by the investment in KM practices] limit just how radical innovation can be. The whole of IT learned from Xerox; they invented the mouse, the GUI, the printer etc. Yet Xerox saw themselves as a photocopying company so they did not back any of their own ideas; Microsoft, Apple, IBM etc. did."

"You have to be at your best to achieve radical process innovation, something will trigger the process but you need to invest, manage and look at it in a concerted way, whilst the incremental change happens in the current environment, so there is less focus - it is about improving bit by bit and needs a different culture to radical change."

\section{DISCUSSION AND CONCLUSIONS}

\subsection{The theoretical contributions}

The study of process innovation is especially vital because the process of interaction between firms and their users improves the propensity of clients to innovate and enhances the quality of service 
provided (Doroshenko et al., 2013). However, promoting process innovation, especially radical process change, is fraught with difficulty as the evidence shows that process change projects often fail to deliver expected results (Abdolvand et al., 2008).

There is keen academic interest in how users and ITS firm collaborate as the viability of such co-creation and its impact on the firm's performance is not well understood (Santos-Vijande et al., 2013). Further, there is a lack of consensus on how user collaboration benefits radical as compared to incremental innovation performance (Gustafsson et al., 2012). We found that user collaboration with existing users mainly impacts incremental process innovation. This indicates that current end-users are a key source of knowledge for ongoing incremental process change. In contrast, the effect of collaboration with prospective end-users is significant only for radical process innovation.

While the importance of KM practices to enhance absorptive capacity is well established, the understanding of the impact of investments in KM practices on the degrees of innovativeness (especially radical change) is limited (Lane et al., 2006). Investments in KM practices are essential for KIBS to transform external learning into firm-specific capabilities (Salter and Tether, 2014). However, researchers have found it challenging to establish a link between KM and organisational outcomes (Heisig, 2015); a topic addressed in this paper. ITS firms invest greater resources in KM practices for radical change, because higher degree of innovativeness pushes the boundaries of current processes and forces the firm to engage in an extensive search of the environment for new knowledge (Ritala and Hurmelinna-Laukkanen, 2013).

We also found that investments in KM practices play a crucial role in extracting value from external (user) knowledge for process innovation. Our findings reinforce the proposition that continuous communication and ongoing knowledge exchange enhance value co-creation between the current customers and the service provider. Existing end-users are so familiar that they may be viewed as endogenous to the service firm's effort to undertake continuous and incremental process change. 
We find that collaboration with prospective users impacts radical process innovation only indirectly, being mediated by investments in KM practices. We argue that radical innovation challenges the firm's current capabilities, knowledge and technology, and triggers the firm's search for novel knowledge from prospective users. However, the extraction of value from new and unfamiliar sources requires greater commitment of resources to enhance internal innovation capabilities. We are, thus, able to validate the theoretical proposition that a firm's innovation capability plays a fundamental role in extracting value from knowledge sources (Lane et al., 2006).

\subsection{The managerial implications}

Process innovation projects often fail to deliver the expected benefits; a problem that particularly applies to radical change. The results obtained by this study are thus intended to provide managers some indications on how user collaboration and investments in KM practices may be adapted to maximise the outputs of radical and incremental process innovation in a KIBS industry.

In relation to user collaboration practices, we find that interaction with existing users seem to be more important for incremental process innovation. This is not surprising as service firms work closely with their users and this ongoing relationship also enables incremental process change. However, managers should note that if a higher degree of process innovativeness is desired, this requires them to search for knowledge that is further away from their current paradigm. We find that ITS providers who adopt radical process innovation depend on, and benefit from, prospective users far more than firms implementing incremental innovation. Existing users seem to find it difficult to understand the need for radically new solutions, as they may be blocked by their previous experience (Menguc et al., 2014). Therefore, ITS managers implementing new-to-market processes will gain by evaluating their problem-solving strategy, and by overcoming the current users' functional fixedness issue by integrating new (prospective) users. 
We find that while collaborating with existing users for incremental process innovation may not require significant managerial efforts (as they are very familiar with the firm, and vice versa), just increasing a firm exposure to external knowledge by engaging with prospective users is not enough to translate this into effective radical innovations. Managers should be aware of the fact that translation of the prospective users' novel ideas into radical solutions will depend on a firm's internal capabilities (Gustafsson et al., 2012). This means that in order to benefit from more intense collaboration with prospective users, a higher managerial effort through investments in KM practices is fully needed so as to be able to develop the absorptive capacity required to transform the external learning into capabilities for radical innovations. Our results and discussions with executives show that developing effective KM practices appear to be critical for KIBS firms to be able to benefit from the more distant knowledge residing within these prospective users. Specifically, we find that the three inward-looking KM practices studied (investment in technological change, training and publishing) and the outward-looking KM practices (investments in benchmarking with direct competitors and market leaders) are likely to be more important for ITS firms to extract value from prospective (as compared to existing) users for radical (as compared to incremental) process change.

\subsection{Limitations and suggestions for further research}

First, the results and conclusions drawn should be viewed in light of the potential sources of bias, operational definitions, focal industry, and sample demographics. Second, over the course of time an innovation may be regrouped across the scale of innovativeness and the distinction between degrees of innovativeness is subjective (Dewar and Dutton, 1986). Third, this paper takes an ex-post view of the differing impact of firm-level factors on radical versus incremental process innovation. Thus, we are unable to corroborate if service firms actually planned the activities to align with their innovation objectives. Fourth, while our group-analysis adheres to the sample size requirements, testing of the research model in a larger sample will reinforce the implications. Fifth, we took a cross-functional 
view in this study, but it should be acknowledged that process innovation steps are iterative in nature.

Hence researchers and managers should note that the use of collaboration and investments in KM practices is expected to vary across the process change journey. Therefore it will be beneficial for future studies to test the hypotheses using a longitudinal design.

Although in this study we tried to shed some light on the role that investments in KM practices may have on a firm's absorptive capacity in a KIBS sector, we believe that further research into the implicit relationship between these two concepts will extend the academic and managerial understanding of how external knowledge is translated into firm-specific capabilities and outcomes.

\section{REFERENCES}

Abdolvand, N., Albadvi, A. and Ferdowsi, Z. (2008), “Assessing readiness for business process reengineering”, Business Process Management Journal, Vol. 14 No. 4, pp. 497-511.

Allison, P. D. (2003), "Missing Data Techniques for Structural Equation Modeling”, Journal of Abnormal Psychology, Vol. 112 No. 4, pp. 545-557.

Anderson, K. and McAdam, R. (2004), “A critique of benchmarking and performance measurement: Lead or lag?", Benchmarking: An International Journal, Vol. 11 No. 5, pp. 465-483.

Armstrong, J. S. and Overton, T. (1977), "Estimating nonresponse bias in mail surveys", Journal of Marketing Research, Vol. 14, pp. 396-402.

Arundel, A., Lorenz, E., Lundvall, B. À. and Valeyre, A. (2006), "The Organization of Work and Innovative Performance: A comparison of the EU-15”, DRUID Working Paper 06-14, pp. 135.

Baron, R. M. and Kenny, D. A. (1986), “The Moderator-Mediator Variable Distinction in Social Psychological Research: Conceptual, Strategic, and Statistical Considerations", Journal of Personality and Social Psychology, Vol. 51 No. 6, pp. 1173-1182.

Bartlett, J. E., Kotrlik, J. W. and Higgins, C. C. (2001), “Organizational research: Determining appropriate sample size in survey research", Information technology, learning, and performance journal, Vol. 19 No. 1, pp. 43.

Baruch, Y. and Holtom, B. C. (2008), "Survey response rate levels and trends in organizational research", Human Relations, Vol. 61 No. 8, pp. 1139-1160.

Bauer, M. and Leker, J. (2013), "Exploration and exploitation in product and process innovation in the chemical industry”, $R \& D$ Management, Vol. 43 No. 3, pp.196-212.

Blackmore, D. and Hale, K. (2012), "Market Definitions and Methodology: IT Services", Gartner, ID:G00230808, pp. 1-51.

Camp, R. C. (1989), Benchmarking: the search for industry best practices that lead to superior performance, ASQC/Quality Resources.

Campbell, D. T. (1955), “The Informant in Quantitative Research”, American Journal of Sociology, Vol. 60 No.4, pp. 339-342.

Chin, W. and Dibbern, J. (2010), “An Introduction to a Permutation Based Procedure for MultiGroup PLS Analysis: Results of Tests of Differences on Simulated Data and a Cross Cultural Analysis of the Sourcing of Information System Services Between Germany and the USA", 
In: Esposito Vinzi, V., Chin, W. W., Henseler, J. and Wang, H. (eds.) Handbook of Partial Least Squares, pp. 171-193.

Chin, W. W. (1998a), "Issues and Opinion on Structural Equation Modeling", MIS Quarterly, Vol. 22 No. 1 , pp. $1-8$

Chin, W. W. (1998b), "The partial least squares approach for structural equation modeling" (Chapter Ten), In: MARCOULIDES, G. A. (eds.) Modern methods for business research, pp. 295-336. Churchill Jr, G. A. (1979), “A Paradigm for Developing Better Measures of Marketing Constructs", Journal of Marketing Research, Vol. 16 No. 1, pp. 64-73.

Cohen, J. (1992), “Quantitative methods in psychology: A power primer”, Psychological Bulletin, Vol. 112 No. 1, pp. 155-159.

Cohen, W. M. and Levinthal, D. A. (1990), “Absorptive capacity: A new perspective on learning and innovation”, Administrative Science Quarterly, Vol. 35 No. 1, pp. 128-152.

Cronbach, L. (1951), "Coefficient alpha and the internal structure of tests", Psychometrika, Vol. 16 No. 3, pp. 297-334.

Damanpour, F. (1991), "Organizational Innovation: A Meta-Analysis of Effects of Determinants and Moderators", The Academy of Management Journal, Vol. 34 No. 3, pp. 555-590.

Damanpour, F. (2010), “An Integration of Research Findings of Effects of Firm Size and Market Competition on Product and Process Innovations", British Journal of Management, Vol. 57 No. 4, pp. 996-1010.

Damanpour, F., Walker, R. M. and Avellaneda, C. N. (2009), "Combinative Effects of Innovation Types and Organizational Performance: A Longitudinal Study of Service Organizations", Journal of Management Studies, Vol. 46 No. 4, pp. 650-675.

Darroch, J. (2003), "Developing a measure of knowledge management behaviors and practices", Journal of Knowledge Management, Vol. 7 No. 5, pp. 41-54.

Dewar, R. D. and Dutton, J. E. (1986), "The adoption of radical and incremental innovations: an empirical analysis", Management Science, Vol. 32 No.11, pp.1422-1433.

Doroshenko, M., Miles, I. and Vinogradov, D. (2013), "Knowledge Intensive Business Services as Generators of Innovations", Higher School of Economics Research Paper No. WP BPR 12/STI/2013, pp. 1-41.

Ettlie, J. E., Bridges, W. P. and O'Keefe, R. D. (1984), “Organization Strategy and Structural Differences for Radical versus Incremental Innovation”, Management Science, Vol. 30 No. 6, pp. 682-695.

Fichman, R. G. and Kemerer, C. F. (1997), "The Assimilation of Software Process Innovations: An Organizational Learning Perspective”, Management Science, Vol. 43 No. 10, pp. 1345-1363.

Foss, N. J., Laursen, K. and Pedersen, T. (2011), "Linking Customer Interaction and Innovation: The Mediating Role of New Organizational Practices”, Organization Science, Vol. 22 No. 4, 980 999.

Garcia, R. and Calantone, R. (2002), “A critical look at technological innovation typology and innovativeness terminology: a literature review", Journal of Product Innovation Management, Vol. 19 No. 2, pp. 110-132.

Gold, A. H., Malhotra, A. and Segars, A. H. (2001), "Knowledge Management: An Organizational Capabilities Perspective", Journal of Management Information Systems, Vol. 18 No. 1, pp. 185-214.

Gulati, R. (1995), "Does Familiarity Breed Trust? The Implications of Repeated Ties for Contractual Choice in Alliances", The Academy of Management Journal, Vol. 38 No. 1, pp. 85-112.

Gustafsson, A., Kristensson, P. and Witell, L. (2012), "Customer co-creation in service innovation: a matter of communication?” Journal of Service Management, Vol. 23 No. 3, pp. 311-327.

Hair, J. F., Hult, G. T. M., Ringle, C. and Sarstedt, M. (2013), A Primer on Partial Least Squares Structural Equation Modeling (PLS-SEM). Sage Publications. 
Heisig, P. (2015), "Future Research in Knowledge Management: Results from the Global Knowledge Research Network Study”, In: Bolisani, E. and Handzic, M. (eds.) Advances in Knowledge Management, pp. 151-182.

Henseler, J., Ringle, C. and Sinkovics, R. R. (2009), "The use of partial least squares path modeling in international marketing", New Challenges to International Marketing, Emerald Group Publishing Limited.

Hertog, P. D. (2000), "Knowledge-Intensive Business Services as Co-Producers of Innovation”, International Journal of Innovation Management, Vol. 4 No. 4, pp. 491-528.

Hienerth, C., Von Hippel, E. and Jensen, M. B. (2014), "User community vs. producer innovation development efficiency: A first empirical study", Research Policy, Vol. 43 No. 1, pp. 190201.

Jansen, J. J. P., Van Den Bosch, F. A. J. and Volberda, H. W. (2006), “Exploratory Innovation, Exploitative Innovation, and Performance: Effects of Organizational Antecedents and Environmental Moderators", Management Science, Vol. 52 No. 11, pp. 1661-1674.

Johnson, R. B., Onwuegbuzie, A. J. and Turner, L. A. (2007), "Toward a Definition of Mixed Methods Research", Journal of Mixed Methods Research, Vol. 1 No. 2, pp. 112-133.

Jones, N. B. and Mahon, J. F. (2012), "Nimble knowledge transfer in high velocity/turbulent environments", Journal of Knowledge Management, Vol. 16 No. 5, pp. 774-788.

Kang, K. H. and Kang, J. (2014), "Do External Knowledge Sourcing Modes Matter for Service Innovation? Empirical Evidence from South Korean Service Firms", Journal of Product Innovation Management, Vol. 31 No. 1, pp. 176-191.

Kim, H., Park, N. and Lee, J. (2014), "How does the second-order learning process moderate the relationship between innovation inputs and outputs of large Korean firms?" Asia Pacific Journal of Management, Vol. 31 No. 1, pp. 69-103.

Lane, P. J., Koka, B. R. and Pathak, S. (2006), "The Reification of Absorptive Capacity: A Critical Review and Rejuvenation of the Construct", The Academy of Management Review, Vol. 31 No. 4, pp. 833-863.

Lietz, P. (2010), "Research into questionnaire design", International Journal of Market Research, Vol. 52 No. 2, pp. 249-272.

Menguc, B., Auh, S. and Yannopoulos, P. (2014), "Customer and Supplier Involvement in Design: The Moderating Role of Incremental and Radical Innovation Capability”, Journal of Product Innovation Management, Vol. 31 No. 2, pp. 313-328.

Nicolajsen, H. W. and Scupola, A. (2011), "KIBS and their users as co-creators of breakthrough innovation", In: Sundbo, J. and Toivone, M. (eds.) User-based Innovation in Services, pp.101-120

Norman, D. A. and Verganti, R. (2014), "Incremental and Radical Innovation: Design Research vs. Technology and Meaning Change", Design Issues, Vol. 30 No. 1, pp. 78-96.

OECD (2005), Oslo manual: Guidelines for collecting and interpreting innovation data, Organisation for Economic Co-operation Development (OECD) publishing.

Olkin, I. and Finn, J. D. (1995), "Correlations redux", Psychological Bulletin, Vol. 118 No. 1, pp. 155-164.

Du Plessis, M. D. (2007), “The role of knowledge management in innovation", Journal of Knowledge Management, Vol. 11 No. 4, pp. 20-29.

Podsakoff, P. M. and Organ, D. W. (1986), "Self-Reports in Organizational Research: Problems and Prospects", Journal of Management, Vol. 12 No. 4, pp. 531-544.

Prahalad, C. K. and Ramaswamy, V. (2004), "Co-creation experiences: The next practice in value creation”, Journal of Interactive Marketing, Vol. 18 No. 3, pp. 5-14.

Reichstein, T. and Salter, A. (2006), "Investigating the sources of process innovation among UK manufacturing firms", Industrial and Corporate Change, Vol. 15 No. 4, pp. 653-682. 
Ridder, F. and Cohen, L. R. (2013), "Outsourcing Trends 2013: The Impact of Social, Information, Mobile and Cloud on Your Sourcing Strategies", Gartner, ID: G00239102, pp. 1-13.

Ringle, C. M., Wende, S. and Will, A. (2005), SmartPLS 2.0, www.smartpls.de.

Ritala, P. and Hurmelinna-Laukkanen, P. (2013), "Incremental and Radical Innovation in Coopetition-The Role of Absorptive Capacity and Appropriability", Journal of Product Innovation Management, Vol. 30 No. 1, pp. 154-169.

Robertson, P. L., Casali, G. L. and Jacobson, D. (2012), "Managing open incremental process innovation: Absorptive Capacity and distributed learning", Research Policy, Vol. 41 No. 5, pp. 822-832.

Salter, A. and Tether, B. S. (2014), "Innovation in Services: An Overview”, In: Haynes, K. and Grugulis, I. (eds.) Managing Services: Challenges and Innovation, pp. 134-153.

Santos-Vijande, M. L., González-Mieres, C. and López-Sánchez, J. Á. (2013), “An assessment of innovativeness in KIBS: implications on KIBS' co-creation culture, innovation capability, and performance", Journal of Business \& Industrial Marketing, Vol. 28 No. 2, pp. 86-102.

Sauermann, H. and Roach, M. (2013), "Increasing web survey response rates in innovation research: An experimental study of static and dynamic contact design features", Research Policy, Vol. 42 No. 1, pp. 273-286.

Schafer, J. L. and Graham, J. W. (2002), "Missing data: our view of the state of the art", Psychological Methods, Vol. 7 No. 2, pp. 147-177.

Schumpeter, J. A. (1961), The theory of economic development: An inquiry into profits, capital, credit, interest, and the business cycle.

Serenko, A. and Dumay, J. (2015), "Citation classics published in knowledge management journals, Part I: articles and their characteristics", Journal of Knowledge Management, Vol. 19 No. 2, pp. 401-431.

Skiba, F. and Herstatt, C. (2008), "Integration of innovative users as source of service innovations", Proceedings of the International Product Development Conference, pp. 1-42.

Sobel, M. E. (1982), “Asymptotic confidence intervals for indirect effects in structural equation models", Sociological Methodology, Vol. 13, pp. 290-312.

Sorescu, A. B., Chandy, R. K. and Prabhu, J. C. (2003), "Sources and Financial Consequences of Radical Innovation: Insights from Pharmaceuticals", Journal of Marketing, Vol. 67 No. 4, pp. 82-102.

Sosik, J. J., Kahai, S. S. and Piovoso, M. J. (2009), "Silver Bullet or Voodoo Statistics?: A Primer for Using the Partial Least Squares Data Analytic Technique in Group and Organization Research", Group \& Organization Management, Vol. 34 No. 1, pp. 5-36.

Tabachnick, B. G. and Fidell, L. S. (2007), Using Multivariate Statistics (5th edition), Pearson.

Tether, B. S. (2002), "Who co-operates for innovation, and why: An empirical analysis", Research Policy, Vol. 31 No. 6, pp. 947-967.

UKIS (2012), "First Findings from the UK Innovation Survey 2011: Science and Innovation Analysis", UK BIS - Department for Business Innovation and Skills. http://www.bis.gov.uk/assets/biscore/science/docs/f/12-p107-first-findings-uk-innovationsurvey-2011

Van Riel, A. C. R., Lemmink, J. and Ouwersloot, H. (2004), "High-Technology Service Innovation Success: A Decision-Making Perspective", Journal of Product Innovation Management, Vol. 21 No. 5, pp. 348-359.

Von Hippel, E. (2005), “Democratizing Innovation”, The MIT Press.

Zahra, S. A. and George, G. (2002), "Absorptive capacity: a review, reconceptualization and extension”, The Academy of Management Review, Vol. 27 No. 2, pp. 185-203.

Zairi, M. and Sinclair, D. (1995), "Business process re-engineering and process management: A survey of current practice and future trends in integrated management", Business Process Reengineering \& Management Journal, Vol. 1 No. 1, pp. 8-30. 


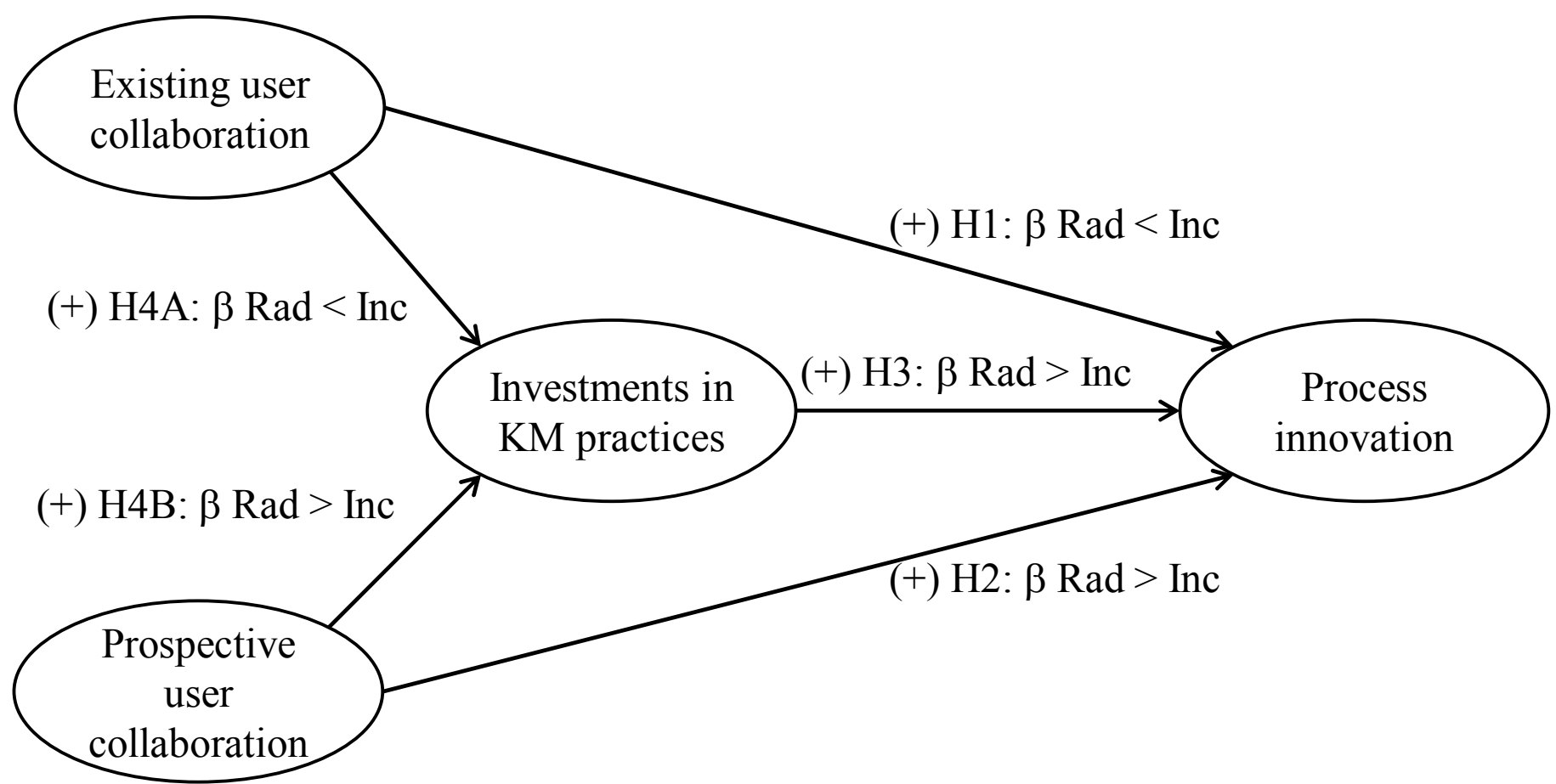

Rad - radical process innovation sub-group

Inc - incremental process innovation sub-group

Figure 1: The differing impact of firm-level factors on process innovation based on the degree of innovativeness 


\section{Notes:}

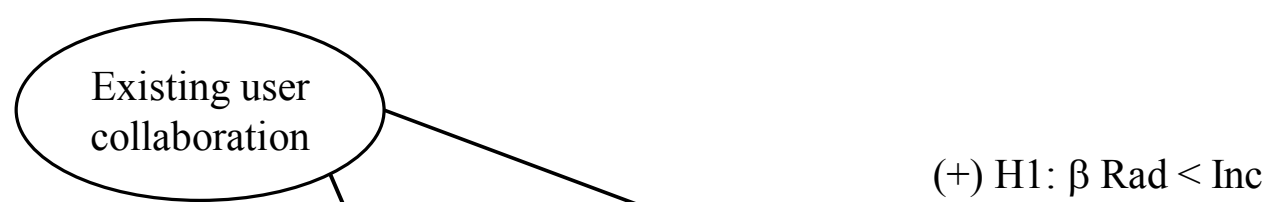

(+) H4A: $\beta \operatorname{Rad}<\operatorname{Inc}$

Rad: $0.13(1.15)$

Inc: $\quad-0.03(0.27)$

Rad: radical process innovation sub-group, Inc: incremental process innovation sub-group Numbers represent standardised path coefficients (t-statistic)

$*$ significant at $0.05, * *$ significant at $0.01 * * *$ significant at 0.001 (all two-tailed)

Numbers in italics and in [ ] are standardised path coefficients (t-statistic) for direct effect

Both the direct effect in the absence of the mediator, and the indirect effect through the mediator are studied

Figure 2: Path assessment - standardised path coefficient (t-statistic) for sub-groups 
Table 1: The measurement scale and model loadings for the degrees of innovativeness

\begin{tabular}{|c|c|c|c|}
\hline The measurement scale and model loadings & & $\begin{array}{l}\text { Process in } \\
\text { groups }(0\end{array}$ & $\begin{array}{l}\text { vation sub- } \\
\text { er loading) }\end{array}$ \\
\hline Construct-Indicators & Measurement scale & Radical & Incremental \\
\hline $\begin{array}{l}\text { Process innovation }(P I) \\
\text { Our organisation has delivered a new or significantly improved process: } \\
\text { PI1 across the business unit } \\
\text { Our organisation delivered 'process innovation' that: } \\
\text { PI2 increased profit margin on sales } \\
\text { PI3 led to new customer acquisition } \\
\text { PI4 provided competitive advantage } \\
\text { PI5 enhanced capability to deliver customer needs }\end{array}$ & $\begin{array}{l}\text { Created five reflective indicators to } \\
\text { capture the depth and breadth of } \\
\text { process innovation outcomes } \\
(O E C D, 2005 ; \text { UKIS, 2012). }\end{array}$ & $\begin{array}{l}0.90 \\
0.89 \\
0.93 \\
0.91\end{array}$ & $\begin{array}{l}0.76 \\
0.83 \\
0.91 \\
0.88\end{array}$ \\
\hline $\begin{array}{l}\text { Investments in KM practices (IKM) } \\
\text { In comparison to the past, in the last year our organisations strategy towards } \\
\text { 'process innovation' has changed and our organisation now: } \\
\text { IKM1 invests more in technological changes } \\
\text { IKM2 invests more in training } \\
\text { IKM3 publishes more case studies, articles, papers and sections in a } \\
\text { book } \\
\text { At the beginning of 'process innovation', our organisation benchmarked the } \\
\text { process against best practices: } \\
\text { IKM4 with direct competitors } \\
\text { IKM5 with market leading companies }\end{array}$ & $\begin{array}{l}\text { Created five reflective indicators. } \\
\text { Three indicators captured inward- } \\
\text { looking investments in KM } \\
\text { practices (Jones and Mahon, 2012; } \\
\text { UKIS, 2012) and two indicators } \\
\text { studied the outward-looking } \\
\text { investments in KM practices of } \\
\text { benchmarking (Camp, 1989; Kang } \\
\text { and Kang, 2014). }\end{array}$ & $\begin{array}{l}0.74 \\
0.82 \\
0.80\end{array}$ & $\begin{array}{l}0.85 \\
0.70 \\
0.78\end{array}$ \\
\hline $\begin{array}{l}\text { Existing user collaboration (EEU) } \\
\text { The end users that collaborated in 'process innovation' with our } \\
\text { organisation: } \\
\text { EEU1 were existing end users }\end{array}$ & $\begin{array}{l}\text { Created one reflective indicator } \\
\text { based on the definition adopted. }\end{array}$ & 1.00 & 1.00 \\
\hline
\end{tabular}




\section{The measurement scale and model loadings}

\section{Construct-Indicators}

Prospective user collaboration (PEU)

The end users that collaborated in 'process innovation' with our organisation:

PEU1 were prospective end users from existing market PEU2 were prospective end users from target markets

\section{Degree of innovativeness}

Estimated percentage split of the 'process innovation' delivered by our organisation last year:

Radical: \% new to the market Incremental: \% new to our organisation (add) \% significantly improved but not new
Process innovation subgroups (outer loading)

\section{Radical Incremental}

Created two reflective indicators

based on the definition adopted.

$\begin{array}{ll}0.96 & 0.93 \\ 0.95 & 0.94\end{array}$

Created three indicators based on the definition adopted. 
Table 2: Sample descriptive analysis

\begin{tabular}{|c|c|c|c|}
\hline \multirow{2}{*}{\multicolumn{2}{|c|}{ Demographic }} & \multicolumn{2}{|c|}{$\begin{array}{c}\text { Percent of sample } \\
\text { (process innovation sub-groups) }\end{array}$} \\
\hline & & Radical & Incremental \\
\hline & Small $(<=50$ employees $)$ & 10 & 5 \\
\hline \multirow[t]{2}{*}{ Firm size } & Medium ( $>50$ and $<=1000$ employees) & 16 & 17 \\
\hline & Large ( $>1000$ employees) & 74 & 77 \\
\hline Country & (rest of) Europe & 12.1 & 14.7 \\
\hline pertaining to & India & 24.1 & 28.0 \\
\hline process & North America & 22.4 & 16.0 \\
\hline innovation & $\mathrm{UK}$ & 29.3 & 29.3 \\
\hline experience & Others & 12.1 & 12.0 \\
\hline
\end{tabular}

19

20

21

22

23

24

25

26

27

28

29

30

31

32

33

34

35

36

37

38

39

40

41

42

43

44

45

46

47

48

49

50

51

52

53

54

55

56

57

58

59

60 
Table 3: Titles and professional experience of the interviewees

\begin{tabular}{|c|c|}
\hline Title & Professional Experience at the time of discussions \\
\hline Principal Consultant & $\begin{array}{l}\text { Over } 31 \text { years, roles include: subject matter expert (QMS, ISO, } \\
\text { CMMi), consultant (business planning, resource planning and } \\
\text { management), Six Sigma (SS)-Master Black Belt (MBB) }\end{array}$ \\
\hline Director & $\begin{array}{l}\text { Over } 21 \text { years, roles include: director, global head - small and } \\
\text { medium business solutions, global head - SS consulting }\end{array}$ \\
\hline President & $\begin{array}{l}\text { Over } 24 \text { years, roles include: chief process officer, executive vice } \\
\text { president, global business innovation lead, COO, VP continental } \\
\text { Europe, CEO of not-for-profit organisation, assistant professor, } \\
\text { researcher (holds a doctorate) }\end{array}$ \\
\hline Business Transformation & er 19 years, rol \\
\hline Manager & $\begin{array}{l}\text { business manager, commercial lead and commercial contracts } \\
\text { manager }\end{array}$ \\
\hline $\mathrm{CEO}$ & $\begin{array}{l}\text { Over } 14 \text { years, roles include: CEO, facilitator, keynote speaker, } \\
\text { trustee of an NGO, software tester, CMM consultant, process } \\
\text { improvement consultant, soft skills trainer, accountant }\end{array}$ \\
\hline Global Account Executive & $\begin{array}{l}\text { Over } 20 \text { years, roles include: director level positions within } \\
\text { business development, growth and transformation }\end{array}$ \\
\hline $\begin{array}{l}\text { Sr. Vice President \& Global } \\
\text { Head - Business Excellence, } \\
\text { Six Sigma \& Organization } \\
\text { Development }\end{array}$ & $\begin{array}{l}\text { Over } 20 \text { years, roles include: business strategy and balanced } \\
\text { scorecard deployment consultant, lean SS deployment lead, } \\
\text { operations manager, lead MBB }\end{array}$ \\
\hline $\begin{array}{l}\text { Industry Transformation } \\
\text { Consultant }\end{array}$ & $\begin{array}{l}\text { Over } 20 \text { years, roles include: innovation services lead, business } \\
\text { strategy and transformational change consultant, VP, member of } \\
\text { journal editorial board, value management researcher, senior } \\
\text { lecturer, } \mathrm{PhD} \text { supervisor and examiner (holds a doctorate) }\end{array}$ \\
\hline $\begin{array}{l}\text { Corporate Process } \\
\text { Improvement Centre of } \\
\text { Excellence, Consultant }\end{array}$ & $\begin{array}{l}\text { Over } 17 \text { years, roles include: subject matter expert - SS-MBB, } \\
\text { process improvement consultant, lead trainer, QA assessor }\end{array}$ \\
\hline Consultant Director & $\begin{array}{l}\text { Over } 23 \text { years, roles include: director of development, consultant } \\
\text { director, QA manager, project manager, research officer }\end{array}$ \\
\hline Associate Practice Leader & $\begin{array}{l}\text { Over } 14 \text { years, roles include: associate director - business process } \\
\text { management solutions \& presales, process improvement consultant, } \\
\text { SS-BB, founder and SBU head }\end{array}$ \\
\hline Global Account Executive & $\begin{array}{l}\text { Over } 21 \text { years, roles include: global account executive, strategic } \\
\text { global pursuit lead, enterprise client delivery executive, IT portfolio } \\
\text { executive, delivery executive }\end{array}$ \\
\hline $\begin{array}{l}\text { Corporate Process } \\
\text { Excellence Consultant; Data } \\
\text { Analysis and Metrics Expert }\end{array}$ & $\begin{array}{l}\text { Over } 13 \text { years (2013), roles include: SS-MBB, consultant } \\
\text { (functional, process improvement), lead trainer for statistics and } \\
\text { quantitative methodology, data visualization and analytics } \\
\text { consultant }\end{array}$ \\
\hline
\end{tabular}


Table 4: The outer model's reliability and validity for the degree of innovativeness sub-groups

\begin{tabular}{|l|cc|cc|}
\hline Constructs & \multicolumn{4}{|c|}{ Process innovation sub-groups } \\
& AVE & Composite reliability & AVE & $\begin{array}{c}\text { Compremental } \\
\text { Composite reliability }\end{array}$ \\
Process innovation & 0.81 & 0.96 & 0.69 & 0.92 \\
Existing user collaboration & 1.00 & 1.00 & 1.00 & 1.00 \\
Prospective user collaboration & 0.91 & 0.95 & 0.87 & 0.93 \\
Investments in KM practices & 0.59 & 0.88 & 0.59 & 0.88 \\
$n$ (sample size) & & 58 & & 75 \\
Model $R^{2}$ & & 0.56 & & 0.35 \\
\hline
\end{tabular}

19

20

21

22

23

24

25

26

27

28

29

30

31

32

33

34

35

36

37

38

39

40

41

42

43

44

45

46

47

48

49

50

51

52

53

54

55

56

57

58

59

60 
Table 5: Discriminant validity, the cross loading test

\begin{tabular}{|c|c|c|c|c|c|c|c|c|}
\hline \multirow[b]{3}{*}{\begin{tabular}{|} 
Constructs \\
Indicators
\end{tabular}} & \multicolumn{8}{|c|}{ Process innovation sub-groups (outer loadings) } \\
\hline & \multicolumn{4}{|c|}{ Radical } & \multicolumn{4}{|c|}{ Incremental } \\
\hline & $\begin{array}{l}\text { Existing user } \\
\text { collaboration }\end{array}$ & $\begin{array}{c}\text { Investments in } \\
\text { KM practices }\end{array}$ & $\begin{array}{c}\text { Process } \\
\text { innovation }\end{array}$ & $\begin{array}{c}\text { Prospective user } \\
\text { collaboration }\end{array}$ & $\begin{array}{l}\text { Existing user } \\
\text { collaboration }\end{array}$ & $\begin{array}{c}\text { Investments in } \\
\text { KM practices }\end{array}$ & $\begin{array}{c}\text { Process } \\
\text { innovation }\end{array}$ & $\begin{array}{c}\text { Prospective use } \\
\text { collaboration }\end{array}$ \\
\hline PII & 0.29 & 0.69 & 0.87 & 0.35 & 0.27 & 0.43 & 0.77 & -0.05 \\
\hline$P I 2$ & 0.13 & 0.68 & 0.90 & 0.39 & 0.10 & 0.31 & 0.76 & -0.02 \\
\hline$P I 3$ & 0.05 & 0.68 & 0.89 & 0.61 & 0.02 & 0.51 & $\mathbf{0 . 8 3}$ & 0.21 \\
\hline PI4 & 0.20 & 0.70 & 0.93 & 0.52 & 0.15 & 0.53 & 0.91 & 0.17 \\
\hline PI5 & 0.21 & 0.62 & 0.91 & 0.31 & 0.24 & 0.43 & 0.88 & 0.08 \\
\hline$I K M 1$ & 0.28 & 0.74 & 0.72 & 0.45 & -0.08 & 0.85 & 0.49 & 0.20 \\
\hline$I K M 2$ & 0.31 & 0.82 & 0.67 & 0.51 & 0.15 & 0.70 & 0.40 & 0.01 \\
\hline$I K M 3$ & 0.12 & 0.80 & 0.47 & 0.36 & -0.16 & 0.78 & 0.44 & 0.13 \\
\hline EEU1 & 1.00 & 0.27 & 0.19 & 0.24 & 1.00 & -0.06 & 0.19 & -0.17 \\
\hline PEU1 & 0.29 & 0.60 & 0.52 & 0.96 & -0.20 & 0.15 & 0.14 & 0.93 \\
\hline PEU2 & 0.16 & 0.53 & 0.40 & 0.95 & -0.13 & 0.20 & 0.05 & 0.94 \\
\hline$I K M 4$ & 0.08 & 0.74 & 0.49 & 0.40 & -0.05 & 0.74 & 0.33 & 0.19 \\
\hline IKM5 & 0.17 & 0.75 & 0.44 & 0.53 & -0.05 & 0.76 & 0.41 & 0.18 \\
\hline
\end{tabular}

Note: the numbers in bold are the highest outer loadings for the indicators. All indicators show higher correlation with their construct, as compared to other constructs. 
Table 6: Discriminant validity, the correlations of constructs and $\sqrt{ }$ AVE test

\begin{tabular}{|c|c|c|c|c|c|c|c|c|}
\hline Constructs & \multicolumn{8}{|c|}{ Process innovation sub-groups (correlations) } \\
\hline & \multicolumn{4}{|c|}{ Radical } & \multicolumn{4}{|c|}{ Incremental } \\
\hline A. Existing user collaboration & $\begin{array}{l}\text { A. } \\
n / a\end{array}$ & B. & C. & D. & $\begin{array}{l}\text { A. } \\
n / a\end{array}$ & B. & $\mathrm{C}$. & D. \\
\hline B. Investments in KM practices & 0.27 & 0.77 & & & -0.05 & 0.77 & & \\
\hline C. Process innovation & 0.19 & 0.75 & 0.90 & & 0.2 & 0.54 & 0.83 & \\
\hline D. Prospective user collaboration & 0.24 & 0.59 & 0.49 & 0.96 & -0.17 & 0.19 & 0.10 & 0.93 \\
\hline
\end{tabular}

Note: The bold and italicised numbers along the diagonal are square root of AVE, and $\boldsymbol{n} / \boldsymbol{a}$ is entered for a single-item construct 
Table 7: Inner model assessment and goodness-of-fit indices for the degree of innovativeness

\begin{tabular}{|c|c|c|c|c|c|c|c|c|c|c|c|c|}
\hline \multirow[b]{2}{*}{ Endogenous constructs } & \multicolumn{6}{|c|}{ Radical process innovation } & \multicolumn{6}{|c|}{ Incremental process innovation } \\
\hline & VIF & $\mathbf{R}^{2}$ & Adj. $\mathbf{R}^{2}$ & $\Delta \mathbf{R}^{2}$ & $\mathbf{f}^{2}$ & $\mathbf{Q}^{2}$ & VIF & $\mathbf{R}^{2}$ & Adj. $\mathbf{R}^{2}$ & $\Delta \mathbf{R}^{2}$ & $\mathbf{f}^{2}$ & $\mathbf{Q}^{2}$ \\
\hline & Values & & a & & & & Values & & & & & \\
\hline Process innovation & & 0.562 & 0.54 & & & 0.44 & & 0.35 & 0.33 & & & 0.20 \\
\hline Existing user collaboration & 1.08 & & & 0.56 & 0.01 & & 1.03 & & & 0.301 & 0.08 & \\
\hline Prospective user collaboration & 1.52 & & & 0.58 & -0.03 & & 1.07 & & & 0.35 & 0.00 & \\
\hline Investments in KM practices & 1.54 & & & 0.27 & 0.68 & & 1.04 & & & 0.07 & 0.42 & \\
\hline Investments in KM practices & & 0.37 & 0.33 & & & 0.21 & & 0.04 & 0.01 & & & 0.02 \\
\hline Existing user collaboration & 1.06 & & & 0.35 & 0.03 & & 1.03 & & & 0.04 & 0.00 & \\
\hline Prospective user collaboration & 1.06 & & & 0.08 & 0.46 & & 1.03 & & & 0.00 & 0.03 & \\
\hline
\end{tabular}

${ }^{\mathrm{a}}$ Adjusted $\mathrm{R}^{2}=1-\left(1-\mathrm{R}^{2}\right) *(\mathrm{n}-1) /(\mathrm{n}-\mathrm{v}-1)$, where $\mathrm{n}=$ sample size and $\mathrm{v}=$ number of predictor variables for the endogenous construct

${ }^{\mathrm{b}} \mathrm{f}^{2}=\left(\mathrm{R}^{2}\right.$ included- $\mathrm{R}^{2}$ excluded $) /\left(1-\mathrm{R}^{2}\right.$ included $)$

${ }^{c}$ cross-validated redundancy approach 
Table 9: Differences in standardised path coefficients across the degree of innovativeness sub-groups

\begin{tabular}{|c|c|c|}
\hline Pathways & t-statistic of path coefficient differences ${ }^{\text {a }}$ & Sig. ${ }^{b}$ \\
\hline $\begin{array}{l}\text { H1 }(+) \text { Existing user collaboration -> Process innovation (direct effect in the absence of } \\
\text { the mediator) }\end{array}$ & -0.84 & ns \\
\hline $\begin{array}{l}\text { H2 }(+) \text { Prospective user collaboration }->\text { Process innovation (direct effect in the absence } \\
\text { of the mediator) }\end{array}$ & 1.91 & 0.03 \\
\hline $\mathrm{H} 3(+)$ Investments in KM practices -> Process innovation & 1.28 & 0.10 \\
\hline \multicolumn{3}{|l|}{ H4A $(+)$ Existing user collaboration -> Process innovation (indirect effect) } \\
\hline Existing user collaboration -> Investments in KM practices & 1.04 & ns \\
\hline Existing user collaboration $->$ Process innovation & -1.87 & 0.03 \\
\hline \multicolumn{3}{|l|}{ H4B (+) Prospective user collaboration -> Process innovation (indirect effect) } \\
\hline Prospective user collaboration -> Investments in KM practices & 2.21 & 0.01 \\
\hline Prospective user collaboration -> Process innovation & 0.19 & ns \\
\hline
\end{tabular}

